\title{
Axotomy inreases CNTF receptor mRNA in rat spinal cord
}

\author{
Marina Mata, Chuan-Fang Jin and David J. Fink \\ Department of Neurology, University of Michigan and GRECC, VAMC, Ann Arbor, MI 48105 (USA)
}

(Accepted 26 January 1993)

Key words: Ciliary neurotrophic factor; Ciliary neurotrophic factor receptor; mRNA; Sciatic nerve; Spinal cord; Polymerase chain reaction

In order to study the role of ciliary neurotrophic factor (CNTF) and its receptor (CNTF-R) in the response of spinal cord neurons to axotomy, we measured the levels of CNTF mRNA in nerve and CNTF-R mRNA in spinal cord following transection of sciatic nerve, using reverse transcriptase PCR. We found CNTF mRNA levels in the nerve fell and that CNTF-R mRNA levels in spinal cord increased at both 1 and 7 days following transection.

Ciliary neurotrophic factor (CNTF) was initially characterized by its ability to support the survival of chick ciliary ganglion cells in vitro ${ }^{1,3,11}$. Subsequently, high amounts of bioactive polypeptide were isolated from the sciatic nerve ${ }^{8,10,21}$, which has proven to be the richest natural source of the polypeptide. In addition to its activity on ciliary ganglion cells, CNTF has been shown to promote the survival of, and neurite outgrowth from, certain sensory and sympathetic neurons ${ }^{3}$ and the survival of motor neurons ${ }^{2}$ in vitro. In vivo CNTF can rescue chick motor neurons from programmed cell death ${ }^{12}$, prevent the axotomy-induced death of immature rat facial nucleus motor neurons ${ }^{16}$, and prevent the degeneration or loss of motor neurons of the phrenic nerve and facial motor nuclei in the $p m n / p m n$ mouse, a model of spinal motor neuron disease ${ }^{17}$.

The role of CNTF in adult rat sciatic nerve, where it is present in high concentrations, remains obscure. The gene for CNTF has been cloned ${ }^{9,20}$, but lacks the concensus leader sequence that would be required for extracellular release of the trophic factor. Unlike nerve growth factor (NGF), whose expression is increased in peripheral nerve following axotomy ${ }^{6}$, CNTF mRNA and polypeptide levels fall in distal nerve following axotomy ${ }^{5,13}$, although there is conflicting evidence re- garding the persistence of immunoreactive and bioactive CNTF in the distal nerve ${ }^{18}$.

More recently, the receptor for CNTF has been identified $^{19}$ and its gene cloned ${ }^{4}$. Unlike the family of NGF receptors, the CNTF receptor lacks a transmembrane domain and is anchored to the membrane via a glycosylphosphatidylinositol linkage, similar to the family of interleukin- 6 receptors ${ }^{7}$. The polypeptide binds $\mathrm{CNTF}$, although other components may be required to mediate a functional response in the cell. CNTF receptors are present in spinal cord neurons in the ventral horn of spinal cord, as demonstrated by in situ hybridization $^{7 \mathrm{a}}$.

In order to explore the possibility that CNTF is involved in the maintenance of normal neuronal integrity and perhaps in the response of neurons to peripheral axotomy, we felt it would be fruitful to explore the response of neuronal CNTF-R mRNA to peripheral axotomy. Increases in CNTF-R mRNA in response to axotomy would suggest that the cell is responding to a loss of CNTF by upregulation of CNTF-R production and therefore support a biological activity for the receptor in the normal state.

The experiments were performed on male (Brown Norway $\times$ Fisher 344 ) $F 1$ hybrid rats, $2-4$ months old and weighing $450-600 \mathrm{~g}$. The animals were anes- 
thetized with chloral hydrate, the sciatic nerve exposed in the gluteal region, cut, and the severed ends reattached with 10-0 ethilon suture. Control rats were anesthetized and the nerve exposed but not cut. 1 day or 7 days after operation, the animals were sacrificed by decapitation and the nerve distal to the ligature and the spinal cord in the region of the lumbar bulge were removed, washed in cold phosphate buffered saline (PBS) and frozen in liquid nitrogen.

Frozen nerves were pulverized under liquid nitrogen using a mortar and pestle, and then suspended in either $2 \mathrm{ml}$ of lysate buffer ( $10 \mathrm{mM}$ EDTA, $0.5 \%$ SDS) or $2 \mathrm{ml}$ of Tri Reagent ${ }^{\mathrm{TM}}$ (Molecular Research Center) and homogenized. Spinal cord was sliced into $2-3 \mathrm{~mm}$ segments and the region of the ventral horn removed using a $1.0 \mathrm{~mm}$ diameter neuro-punch (Fine Science Tools), washed once with cold ethanol, and resuspended in Tri-Reagent. Total RNA was extracted either by the modified SDS-EDTA method ${ }^{15}$, or, for the later samples, using Tri Reagent ${ }^{\mathrm{TM}}$ according to the manufacturer's protocol. Total RNA samples were redissolved in RNAse-free water and the amount of specific mRNA determined by reverse transcriptase polymerase chain reaction (rT-PCR).

Aliquots of the total isolated RNA (200 ng for CNTF, $500 \mathrm{ng}$ for CNTF-R, and $500 \mathrm{ng}$ for GAPDH) were incubated at $64^{\circ} \mathrm{C}$ in $20 \mu \mathrm{l}$ reaction volume containing $1 \times \mathrm{rTth}$ reverse transcriptase buffer $(10 \mathrm{mM}$ Tris- $\mathrm{HCl}, 90 \mathrm{mM} \mathrm{KCl}, \mathrm{pH} 8.3), 1 \mathrm{mM} \mathrm{MnCl}_{2} 200 \mu \mathrm{M}$ dNTPs, 5 units rTth DNA polymerase (Perkin Elmer Cetus) and $1.5 \mu \mathrm{M}$ downstream ( $\left.3^{\prime}\right)$ primer, for $5 \mathrm{~min}$ and then chilled on ice. The cDNA produced was amplified by adding the PCR reaction mixture directly to the reverse transciption tube to yield final concentrations of $1 \times$ PCR buffer, $50 \mu \mathrm{M}$ dNTPs, $2 \mathrm{mM}$ $\mathrm{MgCl}_{2}, 0.4 \mathrm{pM}$ upstream (5') primer, 5 units of $\mathrm{rTth}$ DNA polymerase and $\left[\alpha-{ }^{32} \mathrm{P}\right]-\mathrm{dCTP}(5 \mu \mathrm{Ci} /$ assay $)$ in a final volume of $100 \mu \mathrm{l}$. Amplification at $95^{\circ} \mathrm{C}$ for $1 \mathrm{~min}$ and $60^{\circ} \mathrm{C}$ for $1 \mathrm{~min}$ was carried out for 35 cycles.

For quantitative analysis, $10 \mu \mathrm{l}$ aliquots of the CNTF and CNTF-R PCR products were separated on 5\% polyacrylamide gels and autoradiographed for 10-30 min. The method was quantitative over a range of 32 ng to $1 \mu \mathrm{g}$ of mRNA (Fig. 1). GAPDH PCR products were separated on agarose gels and stained with ethidium bromide.

The PCR primers (synthesized at the UM DNA facility) employed were: CNTF 5' primer: 5-CTT TCG CAG AGC AAA CAC CTC-3; CNTF 3' primer: 5-ACT GTG AGA GCT CTT GAA GGA C-3; CNTF-R 5' primer: 5-CTT GGA GAG CAT CTG GTG GT-3, CNTF-R 3' primer: 5-TTG GGG TAA GTG TTG GAA CGG-3; GAPDH 5' primer: 5-ACC CCT TCA

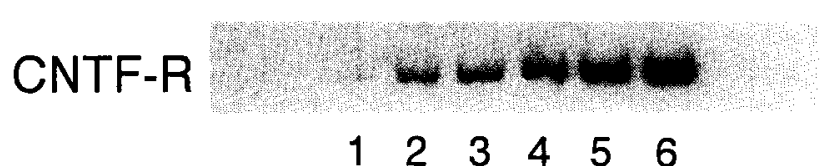

Fig. 1. Signal from reverse transcriptase PCR (rT-PCR) of CNTF-R mRNA is proportional to the amount of total RNA over a wide range of input RNA. Lane 1, $31 \mathrm{ng}$; lane 2, $62.5 \mathrm{ng}$; lane 3, $125 \mathrm{ng}$; lane 4, $250 \mathrm{ng}$; lane 5, $500 \mathrm{ng}$; lane 6,1 $\mu \mathrm{g}$. rT-PCR was carried out with ${ }^{32} \mathrm{P}$-labeled nucleotides as described in text.

TTG ACC TCA ACT A-3; and GAPDH 3' primer: 5-ATT GGG GGT AGG AAC ACG GAA-3. The amplified sequences correspond to residues 5-502 (CNTF)-26-369 (CNTF-R), 97-710 (GAPDH) in the cDNA sequences.

CNTF mRNA was found in the nerve, but not in ventral horn of spinal cord. CNTF-R mRNA was found in ventral horn of spinal cord but not in the nerve. The amount of CNTF mRNA in the nerve, and the amount of CNTF-R mRNA in spinal cord was therefore determined at 1 day and 7 day after nerve transection.

In agreement with previously reported results, using Northern blot techniques ${ }^{5,13}$, CNTF mRNA levels determined by rT-PCR were reduced in the distal nerve after cut. The reduction began by 1 day, and CNTF mRNA was virtually undetectable by 7 days after nerve transection (Fig. 2).

In contrast, the amount of CNTF-R mRNA in spinal cord was increased at 1 day after transection, and at 7 days after transection (Fig. 3).

To control for the amount of RNA used for the first step of the rT-PCR reaction, similar reactions were run with primers specific for GAPDH, a housekeeping enzyme whose level of expression does not change under a variety of experimental manipulations. The amount of GAPDH message was relatively constant across all the conditions (Figs. 4 and 5) and the minor variations found do not account for the dramatic alter-

\section{CNTF (Nerve)}
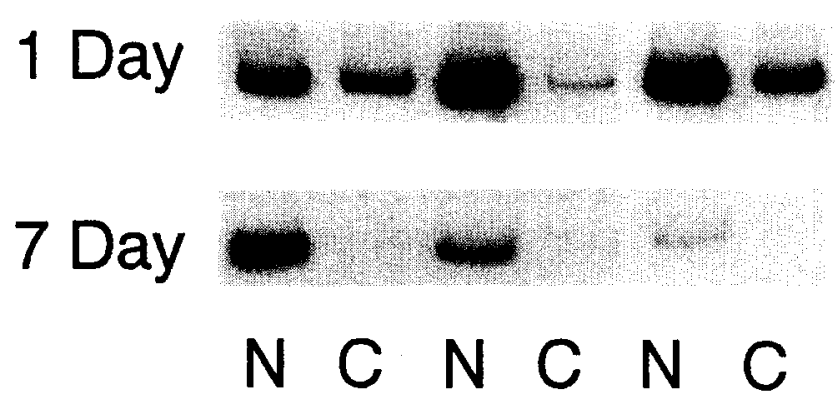

Fig. 2. CNTF mRNA in nerve at 1 day and 7 days following cut, determined by rT-PCR. The results from three different animals at each time point are shown ( $N$, normal nerve; $C$, cut nerve). 


\section{CNTF-R (SC)}

\section{Day}

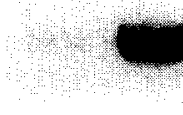

7 Day

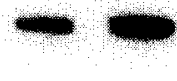

$\mathrm{N} C$

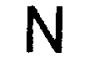

\section{C}

Fig. 3. CNTF-R mRNA in samples punched from ventral horn of spinal cord 1 day and 7 days after nerve cut, determined by rT-PCR. Results from three different animals at each time point are shown (N, normal; $\mathrm{C}$, cut).

ations in the amount of CNTF mRNA in nerve or CNTF-R mRNA in spinal cord.

The role of CNTF in the support of neurons in the mature nervous system has not been established. The in vitro data reviewed above suggests that the polypeptide has neurotrophic activity in vitro. However, the absence of a leader sequence in the gene $e^{9,20}$ has raised questions about whether the polypeptide could be released to function like the better characterized nerve growth factor (NGF) in the peripheral nervous system. Sendtner et al. ${ }^{18}$ found immunohistochemical evidence of signficant amounts of extracellular CNTF in the distal sciatic nerve after a lesion, although mRNA levels were reduced to less than $5 \%$ of normal and CNTF bioactivity was only one third of pre-lesion levels. Others have demonstrated only a marked reduction in CNTF mRNA and protein after lesion ${ }^{5,13}$. While one group has demonstrated immunocytochemical staining of intraaxonal CNTF in sciatic nerve ${ }^{14}$, others have failed to identify intraaxonal $\mathrm{CNTF}^{5}$.

\section{GAPDH (Nerve)}

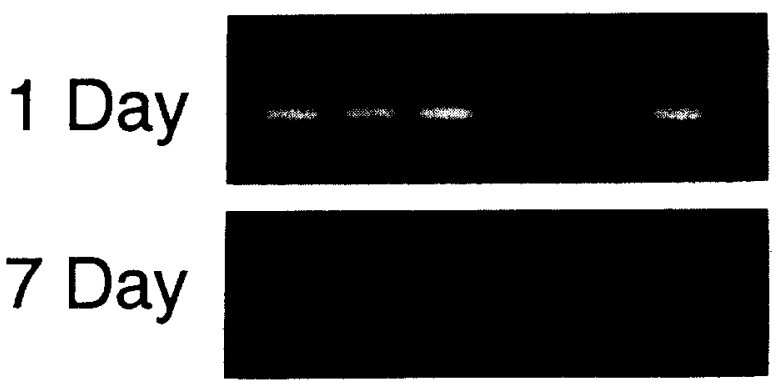

Fig. 4.GAPDH determined from the same nerve mRNA samples as shown in Fig. 2. Ethidium bromide stained gel. As in Fig. 2, lanes 1, 3 and 5 are from normal nerve and lanes 2, 4 and 6 from cut nerve.

\section{GAPDH (SC)}
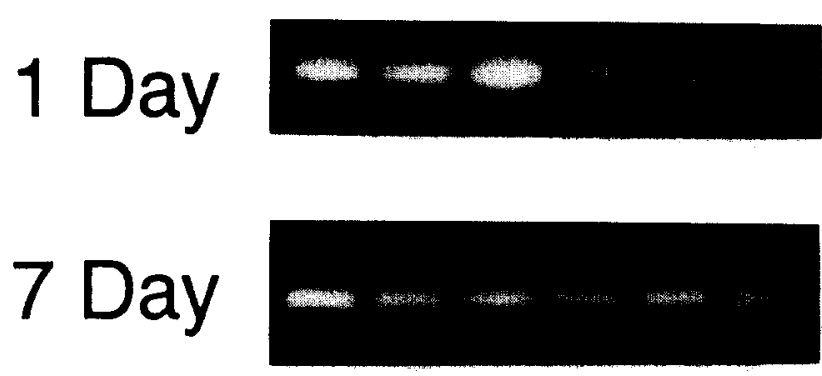

Fig. 5. GAPDH determined from the same spinal cord mRNA samples as shown in Fig. 3. Ethidium bromide stained gel. As in Fig. 3 , lanes 1, 3 and 5 are from normal, and lanes 2, 4 and 6 from cut animals.

Nonetheless, the upregulation of CNTF-R mRNA following axotomy supports the suggestion, expressed by Ip et al. ${ }^{5}$ that the intact peripheral nerve may serve as a reservoir for trophic factors. As those authors have noted previously, neuronal survival following axotomy is proportional to the size of the remaining axon; the number of neurons that die increase when the axotomy is nearer to the cell body ${ }^{22}$. In this model, the increase in CNTF-R mRNA represents the efforts of those cells to maximize the benefit of CNTF produced by Schwann cells along the remaining axon proximal to the cut. Because the PCR primers employed in this study amplify a region of the CNTF-R mRNA sequence which codes for the polypeptide that binds CNTF, but the CNTF-R, like the related family of interleukin receptors, may require a second cell surface component to mediate a functional response, future experiments will be aimed at determining whether cell specific CNTF-R expression correlates with cell survival in the spinal cord.

This work was supported by VA Merit Review Grants (NM and DJF) and Grant NS27771 from the NINDS (DJF). We acknowledge the assistance of Daniel Cutler in creating the figures.

1 Adler, R., Landa, K.B., Manthorpe, M. and Varon, S., Cholinergic neuronotrophic factors: intraocular distribution of trophic activity for ciliary neurons, Science, 204 (1979) 1434-1436.

2 Arakawa, Y., Sendtner, M. and Thoenen, H., Survival effect of ciliary neurotrophic factor (CNTF) on chick embryonic motoneurons in culture: comparison with other neurotrophic factors and cytokines, J. Neurosci., 10 (1990).3507-3515.

3 Barbin, G., Manthorpe, M. and Varon, S., Purification of the chick eye ciliary neuronotrophic factor, J. Neurochem., 43 (1984) $1468-1478$.

4 Davis, S., Aldrich, T.H., Valenzuela, D.M., Wong, V., Furth, M.E., Squinto, S.P. and Yancopoulos, G.D., The receptor for ciliary neurotrophic factor, Science, 253 (1991) 59-63.

5 Friedman, B., Scherer, S.S., Rudge, J.S., Helgren, M., Morrisey, D., McClain, J., Wang, D., Wiegand, S., Furth, M.E., Lindsay, R.M. and Ip, N.Y., Regulation of ciliary neurotrophic factor 
expression in myelin-related Schwann cells in vivo, Neuron, 9 (1992) 295-305.

6 Heumann, R., Lindholm, D., Bandtlow, C., Meyer, M., Radeke, M.J., Misko, T.P., Shooter, E. and Thoenen, H., Differential regulation of mRNA encoding nerve growth factor and its receptor in rat sciatic nerve during development, degeneration, and regeneration: role of macrophages, Proc. Natl. Acad. Sci. USA, 84 (1987) 8735-8739.

7 Ip, N.Y., Nye, S.H., Boulton, T.G., Davis, S., Taga, T., Li, Y., Birren, S.J., Yasukawa, K., Kishimoto, T. and Anderson, D.J., CNTF and LIF act on neuronal cells via shared signaling pathways that involve the IL-6 signal transducing receptor component gp130, Cell, 69 (1992) 1121-1132.

7a Ip, N.Y., McClain, J., Barrezueta, N.X., Aldrich, T.H., Pan, L., Li, Y., Wiegand, S.J., Friedman, B., Davis, S. and Yancopoulos, G.D., The $\alpha$ component of the CNTF receptor is required for signaling and defines potential CNTF targets in the adult and during development, Neuron, 10 (1993) 89-102.

8 Lin, L.F., Armes, L.G., Sommer, A., Smith, D.J. and Collins, F., Isolation and characterization of ciliary neurotrophic factor from rabbit sciatic nerves, J. Biol. Chem., 265 (1990) 8942-8947.

9 Lin, L.F., Mismer, D., Lile, J.D., Armes, L.G., Butler III, E., Vannice, J.L. and Collins, F., Purification, cloning, and expression of ciliary neurotrophic factor (CNTF), Science, 246 (1989) $1023-1025$.

10 Manthorpe, M., Skaper, S.D., Williams, L.R. and Varon, S., Purification of adult rat sciatic nerve ciliary neurotrophic factor, Brain Res., 367 (1986) 282-286.

11 Nishi, R. and Berg, D.K., Dissociated ciliary ganglion neurons in vitro: survival and synapse formation, Proc. Natl. Acad. Sci. USA, 74 (1977) 5171-5175.

12 Oppenheim, R.W., Prevette, D., Qin-Wei, Y., Collins, F. and MacDonald, J., Control of embryonic motoneuron survival in vivo by ciliary neurotrophic factor, Science, 251 (1991) 16161618.

13 Rabinovsky, E.D., Smith, G.M., Browder, D.P., Shine, H.D. and
McManaman, J.L., Peripheral nerve injury down-regulates CNTF expression in adult rat sciatic nerves, J. Neurosci. Res., 31 (1992) 188-192.

14 Rende, M., Muir, D., Ruoslahti, E., Hagg, T., Varon, S. and Manthorpe, M., Immunolocalization of ciliary neurotrophic factor in adult rat sciatic nerve, GLIA, 5 (1992) 25-32.

15 Sambrook, J., Fritsch, E.F. and Maniatis, T., Molecular Cloning: A Laboratory Manual, Cold Spring Harbor Laboratory Press, Cold Spring Harbor, New York, 1989.

16 Sendtner, M., Kreutzberg, G.W. and Thoenen, H., Ciliary neurotrophic factor prevents the degeneration of motor neurons after axotomy, Nature, 345 (1990) 440-442.

17 Sendtner, M., Schmalbruch, H., Stockli, R.A., Carroll, P., Kreutzberg, G.W. and Thoenen, H., Ciliary neurotrophic factor prevents degeneration of motor neurons in mouse mutant progressive motor neuropathy, Nature, 358 (1992) 502-504.

18 Sendtner, M., Stockli, K.A. and Thoenen, H., Synthesis and localization of ciliary neurotrophic factor in the sciatic nerve of the adult rat after lesion and during regeneration, J. Cell Biol., 118 (1992) 139-148.

19 Squinto, S.P., Aldrich, T.H., Lindsay, R.M., Morrissey, D.M., Panayotatos, N., Bianco, S.M., Furth, M.E. and Yancopoulos, G.D., Identification of functional receptors for ciliary neurotrophic factor on neuronal cell lines and primary neurons, Neuron, 5 (1990) 757-766.

20 Stockli, K.A., Lottspeich, F., Sendtner, M., Masiakowski, P., Carroll, P., Gotz, R., Lindholm, D. and Thoenen, H., Molecular cloning, expression and regional distribution of rat ciliary neurotrophic factor, Nature, 342 (1989) 920-923.

21 Williams, L.R., Manthorpe, M., Barbin, G., Nieto-Sampedro, M., Cotman, C.W. and Varon, S., High ciliary neurotrophic specific activity in rat peripheral nerve, Int. J. Dev. Neuroscience, 2 (1984) 177-180.

22 Ygge, J., Neuronal loss in lumbar dorsal root ganglia after proximal compared to distal sciatic nerve resection: a quantitative study in the rat, Brain Res., 478 (1989) 193-195. 